\title{
Transylvanian Folk Music in Zoltán Kodály’s Compositions
}

\author{
István ALMÁsI \\ Folklore Archives of the Romanian Academy in Cluj/Kolozsvár \\ Str. Republicii nr. 9, Cluj-Napoca RO-400015, Romania \\ E-mail: almasi.samu@gmail.com
}

(Received: November 2017; accepted: January 2018)

\begin{abstract}
Zoltán Kodály became seriously interested in Transylvanian folk music when he had learnt about the results of Béla Bartók's collecting fieldworks in Székelyföld. The wealth of old-style tunes and classical ballads, and - above all - the recognition of the importance of pentatony inspired Kodály to take part personally in the exploration of Székely folk music. Székely musical folklore obviously intrigued him both as an ethnographer and as a composer. He collected nearly 600 tunes in 15 Székely localities in the Gyergyó Basin, the valley of the Kászon stream, and Bukovina. He arranged 66 of these melodies within such compositions as e.g. the Dances of Marosszék, the musical play The Spinning Room, Hungarian Folk Music (57 ballads and folk songs for voice and piano), Székely Lament for mixed voices, Bicinia Hungarica, Kádár Kata and Molnár Anna (both with chamber orchestra accompaniment), and Pentatonic Music. Apart from his own collection, he also used those of some of his contemporaries. The paper discusses the specificities of Kodály's techniques of arrangement. His inspiring advice for younger folklorists had an essential role in triggering the in-depth investigation of Central Transylvanian folk music.
\end{abstract}

Keywords: Kodály, folk music and art music, Transylvania

In Zoltán Kodály's extremely rich œuvre, the activity of the scholar, the composer, the pedagogue, the organizer of a discipline, and the publicist all served a single purpose: to create Hungarian music and musical culture at a European level. To 
this end, his main aim as a composer was "to cultivate art music from the roots of folk music," as he put it succinctly. ${ }^{1}$

It was an irrefutable fact for Kodály that Hungarian folk music - and the whole of Hungarian traditional culture - is the aggregate of basically homogeneous spiritual products in all regions of the language territory. Nevertheless, he devoted signal attention to the folk tradition of Transylvania abounding in ancient values. Proof of it is, for example, the "prolegomenon" written by him for the volume of Erdélyi magyarság. Népdalok (Hungarians from Transylvania. Folksongs) compiled in collaboration with Béla Bartók and published in 1923. At the beginning, in an emphatic place we can read:

... Transylvania as the treasure-house of the archaisms of the Hungarian language, folk poetry and folk art has long been in first place ... it is also richer and more original than any other of our regions .... .

Already as a university student Zoltán Kodály had the opportunity to meet with Transylvanian folksongs through Béla Vikár's phonograph recordings. Nor did he overlook the series published between 1901 and 1913 by János Seprődi in Ethnographia with the title Marosszéki dalgyüjtemény (Collection of songs from Marosszék). ${ }^{3}$ However, it was his acquaintance with the results of Béla Bartók's fieldwork in Székelyföld that kindled his interest in earnest. The wealth of old style tunes and classical ballads, and particularly the recognition of the significance of pentatony, gave Kodály great impetus to take part in the exploration and thorough examination of Székely folk music. Obviously, the Székely folk music tradition intrigued him not only as a folklorist but also as a composer.

In March 1910, he set out on his first trip to Székelyföld. In the Gyergyó Basin he visited five settlements among those where Bartók had not been three years earlier. He recorded on phonograph cylinders or notated on the spot 123 tunes (111 with words, 12 instrumental tunes). Several ballads, plaintive songs, drinking and funny songs he found there became famous as gems of folksong publications and in excellent arrangements. In the spring of 1912 Kodály visited the villages in a characteristic area of the Csík Mountains: the valley of the Kászon stream.

1. “... a népzene gyökeréről nevelni magasabb müzenét.” Zoltán Kodály, "Népzene és müzene” [Folk music and art music], in Úr és paraszt a magyar élet egységében [Gentlemen and peasants in the unity of Hungarian life], ed. Sándor Eckhardt (Budapest: Pázmány Péter Katolikus Egyetem BTK Magyarságtudományi Intézete, 1941), 215. Reprinted in Visszatekintés. Összegyüjtött írások, beszédek, nyilatkozatok [Recollections. Collected writings, speeches, statements], ed. Ferenc Bónis (Budapest: Argumentum, 2007), vol. 2, 263.

2. “... Erdély, mint nyelvi, népköltészeti és népművészeti régiségeink kincsesháza, régtől fogva első helyen áll. Hogy népzene tekintetében is gazdagabb, eredetibb minden más vidékünknél, csak az utóbbi évtizedek gyűjtő munkája mutatta meg." Béla Bartók and Zoltán Kodály, Erdélyi magyarság. Népdalok (Budapest: Népies Irodalmi Társaság - Rózsavölgyi és Társa, [1923]), 5. (Visszatekintés, vol. 3, 287.)

3. János Seprődi, "Marosszéki dalgyüjtemény" [Song collection from Marosszék] Ethnographia 12/8 (1901), 359-372; 13/9 (1902), 416-428; $17 / 4$ (1906), 243-249; $17 / 5$ (1906), 298-307; 23/4 (1912), 225-231; 23/6 (1912), 294-298; 23/7 (1912), 352-359; 24/1 (1913), 36-49. 
He collected 169 tunes (of which 49 were instrumental tunes). Another two years later, in April 1914, he travelled to the Székely villages of Bukovina and in two weeks no fewer than 292 tunes (250 vocal and 42 instrumental) were collected.

Zoltán Kodály's research in the three visited regions resulted in 584 tunes from 15 localities. How does this folk music material appear in his compositions? As is well known, a considerable part of his compositions were written for music pedagogical purposes. He arranged 66 Transylvanian tunes in the works listed in Table 1. In the listed compositions Kodály did not solely rely on the results of his own researches. He also used data from the collections of Béla Bartók, Béla Vikár, László Lajtha, Pál Bodon, János Seprődi, Péter Balla, Imre Balabán, János Csíky, Antal Molnár, and Gábor Veress.

TABLE 1 Kodály's compositions based on Transylvanian folk songs

\begin{tabular}{|l|l|}
\hline $1910-1918$ & $\begin{array}{l}\text { Seven Piano Pieces op. 11 } \\
\text { no. 2 Székely keserves (Transylvanian Lament) } \\
\text { no. 6 Székely nóta (Székely Folksong) }\end{array}$ \\
\hline 1917 & $\begin{array}{l}\text { Magyar rondo (Hungarian Rondo), for cello and piano } \\
\text { Régi magyar katonadalok (Old Hungarian Soldiers' Songs), for chamber } \\
\text { orchestra } \\
\text { no. 5 Csürdöngölö (Barn stamping) }\end{array}$ \\
\hline $1917-1932$ & $\begin{array}{l}\text { Magyar népzene (Hungarian Folk Music), 57 ballads and folksongs for voice and } \\
\text { piano in 10 booklets }\end{array}$ \\
\hline $1924-1932$ & $\begin{array}{l}\text { Székely fonó (The Spinning Room), musical play "Hungarian life in } \\
\text { Transylvania," including 34 folksongs and ballads }\end{array}$ \\
\hline 1925 & $\begin{array}{l}\text { Túrót eszik a cigány (“The Gypsy's eating cottage cheese"), two folksongs for } \\
\text { children's choir }\end{array}$ \\
\hline $1925-1927$ & Háry János, musical play \\
\hline 1927 & Marosszéki táncok (Dances of Marosszék), for piano \\
\hline 1928 & $\begin{array}{l}\text { Cigánysirató (Gypsy Lament), for children's choir (1st tune from Andrásfalva/ } \\
\text { Bukovina, 2nd tune from Magyargyerömonostor/Kalotaszeg) }\end{array}$ \\
\hline 1930 & Marosszéki táncok, orchestral version \\
\hline 1934 & Székely keserves, for mixed voices \\
\hline 1936 & Molnár Anna, Székely folk ballad for mixed voices \\
\hline $1937-1942$ & Bicinia Hungarica, in 4 booklets \\
\hline 1943 & Kádár Kata and Molnár Anna, for voice and chamber orchestra \\
\hline 1945 & Ötfokú zene (Pentatonic Music) \\
\hline 1950 & Túrót eszik a cigány, two folk songs for mixed voices \\
\hline
\end{tabular}


Musicologists have found that Kodály used one or another tune in several compositions. ${ }^{4}$ For example the melody of the song Sir az út elöttem (The road ahead of me is weeping) notated in Kászonimpér in 1912 can be discerned in Seven Piano Pieces, The Spinning Room, Hungarian Folk Music, and Pentatonic Music. On the other side, in The Spinning Room not only tunes from Székelyföld can be heard - as the Hungarian title (Székely fonó, that is, "the Székely spinning room") would suggest - but also some tunes from the Zobor region. Similarly, the first melody of his choral composition The Gypsy's eating cottage cheese was collected by Kodály in Istensegits (Bukovina) in 1914, while the second song with the text incipit Csipkefa bimbója (The bud of the rose tree) comes from Vizslás (Nógrád County), and was collected in 1922.

One of Kodály's devices of composition - and a much favored one, too - was to alloy different variants. Kodály was namely quick to realize during fieldwork that folksongs preserved by the oral tradition and the different variants of a type represented diverse traditional stages between the possibly perfect form and the eroded, defective, fragmentary form. He often found old-style tunes of presumably great value in the stage of decay, which prompted him to write in 1919 in his article A székely népdalról (About Székely folk song):

Gradually the image of a unified Hungarian musical language, a monumental style polished diamond-hard by an old tradition is emerging from the Székely songs and from more or less similar other Hungarian old tunes, and if we collect and piece together the shards of this style into a whole, it may launch great development. ${ }^{5}$

That is also why he sometimes paired a tune found in one region with the lyrics recorded in another area. He also borrowed words from nineteenth-century collections when they fitted more smoothly in content or form to his idea. When however, he arranged a folk song or ballad the text and tune of which perfectly satisfied the rules of the represented style, he did not alter anything of the authentically notated peasant performance throughout several strophes.

Although Zoltán Kodály's fieldwork between 1910 and 1914 was restricted to Székely settlements, he was interested in other areas as well. His encouraging words and advice to young folklorists had a catalytic role in starting in-depth research into Central Transylvanian folk music. Very important results were

4. See János Bereczky, Mária Domokos, Imre Olsvai, Katalin Paksa, and Olga Szalay, Kodály népdalfeldolgozásainak dallam-és szövegforrásai [Melodic and textual sources of Kodáy's folksong arrangements] (Budapest: Zenemükiadó, 1984).

5. “A székely dalokból és a hozzájuk többé-kevésbé közelálló más régi dallamainkból lassankint feldereng egy egységes magyar zenei nyelv képe, egy régi tradíciótól keményre csiszolt, monumentális stílusé, amely, ha darabokban hevertéből összeszedjük és eggyé illesztjük, még nagy fejlődés indítója lehet." Kodály Zoltán, “A székely népdalról," Ifjak Szava 1/7-8 (1919), 17. (Visszatekintés, vol. 1, 19.) 
achieved when researchers acted upon Kodály's advice. For example, when in 1940 László Lajtha wanted to collect Transylvanian folk music but could not decide whether to go to Kalotaszeg or Szék, he asked Kodály for guidance:

Kodály answered the question without a moment of hesitation, saying that he had just seen some embroideries from Szék. Where there is such beautiful and special embroidery, he said, there must be some interesting music as well. He spoke with enthusiasm and urged me to go to Szék.

- Lajtha wrote in his study entitled "Újra megtalált magyar népdaltípus" (A rediscovered Hungarian folksong type). ${ }^{6}$ Lajtha's Szék collection has revealed that in the Transylvanian Plain there was a high-level traditional instrumental folk music and as a corollary, a peculiar, mostly slow tune type, built of extended lines, flourished there. Some of the results of his Szék fieldworks were published already in 1943 in his above-mentioned study. The complete collection only appeared in 1954. ${ }^{7}$ It should be noted, however, that already a decade earlier Pál Járdányi found the same kind of tunes in Kide in the Borsa Valley - his collection was published in $1943 .{ }^{8}$ Not finding their adequate place among the classes of the general folksong collection, Járdányi also solicited Kodály's opinion. Upon Ko dály's advice these typical Transylvanian dance tunes of rather loose structure were grouped separately and received the (by intention temporary, but since then consolidated) designation "jaj-song," alluding to the frequent occurrence of substitute syllables like "jajaja," "hajaha," "lalala," "tararara," and the like. Their names used by the peasantry include: "hajnali" (dawn song), "hajnali cigánytánc" (Gypsy dance at dawn), "hajnali keserves" (plaintive song at dawn), "hajnali csárdás" (csárdás at dawn), "lassú csárdás" (slow csárdás), and "cigánykesergő" (Gypsy lament). Sporadically, earlier folksong collections also included "jaj-songs." There real significance, however, was not realized before Lajtha's Szék collection and Járdányi’s Kide research. The extensive exploratory work in the Transylvanian Plain started in Szék and it essentially modified our overall knowledge of the Hungarian folk music.

What could better prove the significance Kodály attributed to Lajtha's discovery in Szék than the fact that he also paid pilgrimage to the noted settlement on 24 May 1943, after the celebrations staged in honor of his sixtieth birthday in

6. "Kodály habozás nélkül válaszolt s elmondotta, hogy nemrégiben széki hímzéseket látott. Ahol ilyen szép és sajátos hímzések élnek még ma is, kell ott - mondotta - valami érdekes muzsikának is lennie. Lelkesen beszélt s erősen biztatott a széki útra." László Lajtha, "Újra megtalált magyar népdaltípus," in Emlékkönyv Kodály Zoltán hatvanadik születésnapjára = Mélanges offerts à Zoltán Kodály à l'occasion de son soixantième anniversaire, ed. Béla Gunda (Budapest: Magyar Néprajzi Társaság, 1943), 219.

7. László Lajtha, Széki gyüjtés [Collection from Szék] (Budapest:Zeneműkiadó, 1954) (= Népzenei mono gráfiák 2).

8 Pál Járdányi, A kidei magyarság világi zenéje [Secular music of the Hungarians from Kide] (Kolozsvár: Minerva, 1943). 
Kolozsvár. He wanted to hear the peculiar tunes in their native environment. The composer Ferenc Farkas (1905-2000), who called himself "an illegitimate disciple of Kodály," ${ }^{\prime \prime}$ was also involved in the preparations of the trip. ${ }^{10} \mathrm{He}$ recalled the visit of Kodály in the following words:

Kodály's program also included an excursion to Szék. ... we had notified the pastor of the village to invite the women who had sung folk songs for recordings. ... The women had indeed gathered at the parsonage of Szék, there was great singing. Kodály kept notating the fine tunes attentively. ${ }^{11}$

It is a fine piece of evidence of Kodály's greatness as a human being and a scholar that the retired professor of the Music Academy, the world-famous composer and ethnomusicologist hurried from the festivities organized in his honour to out-ofthe-way Szék to acquire first-hand experience of the special values of a freshly discovered ethnographic treasury.

9. Így láttuk Kodályt. Nyolcvannyolc emlékezés [That's how we saw Kodály. Eighty-eight recollections], ed. Ferenc Bónis (Budapest: Balassi-Kodály Zoltán Emlékmúzeum és Archívum, 42017 [11984]), 385.

10. Farkas taught composition in the early 1940s as a professor of the Kolozsvár (Cluj) Conservatory, later as the head of the Composition Department at the Budapest Liszt Academy of Music. He was among others the professor of such composers as György Ligeti and György Kurtág.

11. "Kodály programján egy széki kirándulás is szerepelt. ... Az előadás után közöltem vele, hogy értesítettük a széki papot, gyüjtse össze mindazokat az asszonyokat, akik lemezre énekeltek népdalokat. ... Széken valóban összegyültek az asszonyok a papéknál, volt nagy éneklés, Kodály figyelmesen jegyezte a szép dallamokat.” Bónis (ed.), Így láttuk Kodályt, 385-386. 